\title{
О. П. Аматьєва
}

кандидат педагогічних наук, доцент, доцент кафедри практичної психології ДВНЗ «Донбаський державний педагогічний університет»

М. О. Демченко

аспірант кафедри педагогіки і методики технологічної та професійної освіти ДВНЗ «Донбаський державний педагогічний університет»

В. О. Гакало

студентка педагогічного факультету ДВНЗ «Донбаський державний педагогічний університет»

\section{ВИКОРИСТАННЯ МОЖЛИВОСТЕЙ РОБОТИ РЕСУРСНОГО ЦЕНТРУ ДЛЯ ОПТИМІЗАЦІЇ ПІДГОТОВКИ ПСИХОЛОГО-ПЕДАГОГІЧНИХ ПРАЦІВНИКІВ}

В статті проаналізовано роботу Ресурсного центру - валеонасиченого освітнього простору для розвитку студентів, педагогів, психологів, батьків та дітей ДВНЗ «Донбаський державний педагогічний університет». Визначено провідну ідею та мету роботи Ресурсного центру. Наголошено, що діяльність Ресурсного центру педагогічного фракультету як валеонасиченого освітнього простору для розвитку студентів, педагогів, психологів, батьків та дітей спрямовано на забезпечення фрункціонування зворотних зв'язків між його учасниками.

Представлено результати роботи Ресурсного центра, а саме: кількість залучених партнерів (педагогічних працівників дошкільних навчальних закладів, загальноосвітніх шкіл) та Сертифрікатів про розміщення провідного психолого-педагогічного досвіду на електронній сторінці Ресурсного центру, випусків науково-методичного журналу «Альманах психолого-педагогічного досвіду», науково-методичних посібників, статей у наукових журналах України та за ї̈ межами. Описано роботу Ресурсного центру в освітньому процесі педагогічного факультету ДВНЗ ДДПУ.

Висвітлено роботу освітнього блогу «Ресурсний центр - валеонасичений освітній простір для розвитку студентів, педагогів, психологів, батьків та дітей», який має наступні можливості: здійснення зворотного зв'язку з користувачами; завантаження розміщених матеріалів; пошук інформачії за ключовими словами; відбиття кількості переглядів користувачів. Схарактеризовано структуру та наповнення освітнього блогу. Сторінки основного меню: «Головна», «Про РЦ», "Новини», «Консультанти РЦ», «Бюлетень РЦ», «Публікації про нас», «Для психолого-педагогічних працівників», "Для фрахівців соціальної сфрери», «Альманах психолого-педагогічного досвіду», «Про автора», «Контакти»; сторінки перехресної колонки ліворуч (cross-column): «Наші партнери», «На допомогу студентам (підручники оn-line)».

Визначено, що інфрормаційним ядром Ресурсного центру є унікальна інтелектуальна база викладачів вишу та забезпечення доступу до інфоормаційних, науково-методичних, навчальних інфоормаційних ресурсів із можливістю трансформувати себе і суспільство.

Ключові слова: ресурсний центр, студенти, освітній блог, педагогічні працівники, заклад дошкільної освіти.

Постановка проблеми. Сучасний освітній процес із його швидкоплинними змінами ускладнює орієнтування та профресійне самовизначення педагогів і психологів у розв'язанні актуальних проблем освіти. Недостатнє фінансування закладів дошкільної освіти та шкіл ускладнює мінімізацію цих проблем. Крім того, у сучасному соціумі слабко організована робота з педагогізації населення залишає більшість молодих сімей наодинці з їхніми проблемами щодо виховання та розвитку дітей у межах валеонасиченого простору, унаслідок чого вони (проблеми) лише загострюються. Відтак, створення Ресурсного центру сприяє розвитку профресійно-ме- тодичної компетентності студентів, педагогів та психологів, психолого-педагогічної обізнаності батьків дітей дошкільного та шкільного віку.

Аналіз останніх досліджень і публікацій. Аналіз вітчизняних розвідок за темою дослідження дозволяє стверджувати, що розробляється проблема організації діяльності ресурсних центрів для соціальних працівників, реалізації різних соціальних проектів (Н. Заверико, Т. Лях, І. Новікова, Н. Троценко та інші). Їхню діяльність присвячено висвітленню досвіду організації та роботи ресурсних центрів для реалізації різноманітних проблем соціальної роботи [5]. 
Аналіз закордонних досліджень виявив спрямованість роботи ресурсних центрів на супроводження інклюзивних процесів у закладах освіти (Г. Тархова), на розв'язання питань управління ресурсним центром закладів освіти (О. Зотова) тощо [2; 4].

Мета статті. Проаналізувати роботу Ресурсного центру педагогічного фракультету ДВНЗ «Донбаський державний педагогічний університет».

Виклад основного матеріалу. На сучасному етапі Україна зазнає значних соціально-економічних, духовних і культурних перетворень, що вимагають від вищої школи виховання нового покоління. У зв'язку із цим триває пошук освітніх технологій, які б сприяли особистому та професійному зростанню майбутніх фахівців та забезпечували взаємодію всіх учасників освітнього процесу.

3 цією метою було започатковано реалізацію інноваційного проекту «Ресурсний центр - валеонасичений освітній простір для розвитку студентів, педагогів, психологів, батьків та дітей» на педагогічному фракультеті ДВНЗ «Донбаський державний педагогічний університет».

Провідна ідея роботи Ресурсного центра поєднання наукового потенціалу викладачів ДВНЗ «Донбаський державний педагогічний університет» та практичних працівників для підвищення ефрективності підготовки фрахівців із дошкільної освіти, практичної психології, соціальної роботи, соціального забезпечення.

Мета роботи Ресурсного центра - забезпечення професійно-методичної компетентності студентів, формування їхньої педагогічної обізнаності в різних формах інформаційно-комунікативної та професійної взаємодії на основі діяльності Ресурсного центра.

Діяльність Ресурсного центру педагогічного фракультету як валеонасиченого освітнього простору для розвитку студентів, педагогів, психологів, батьків та дітей спрямовано на забезпечення функціонування зворотних зв'язків між його учасниками, а саме: викладачами вишу, студентами, педагогами-практиками дошкільних навчальних закладів і загальноосвітніх шкіл, практичними психологами закладів освіти, соціальними педагогами, батьками дітей дошкільного та шкільного віку. Для забезпечення психолого-педагогічної та науково-методичної підтримки всіх учасників освітнього процесу в дошкільних навчальних закладах, школах та у вишах проектом передбачено накопичення інформаційних ресурсів для обміну між учасниками, розробку методичного забезпечення з урахуванням потреб усіх учасників освітнього процесу, залучення до створення та експериментальної апробації методичних посібників викладачів та педагогів-практиків і психологів [1].

Ресурсний центр як валеонасичений простір включає сукупність умов для самореалізації особистості в напрямку збереження здоров'я, фрормування здорового способу життя, а саме:

- «Якісна освіта» - отримання якісної освіти закладає основу для поліпшення умов життя людей і забезпечення сталого розвитку. Робота в Ресурсному центрі $\epsilon$ однією із фрорм підвищення кваліфікації викладачів закладу вищої освіти;

- «Партнерство заради сталого розвитку» - Ресурсний центр створює умови для взаємодії викладачів, студентів, педагогічних працівників та батьків дітей дошкільного та шкільного віку з метою популяризації провідного психолого-педагогічного досвіду.

Робота Ресурсного центра педагогічного факультету ДВНЗ «Донбаський державний педагогічний університет» розпочалася у березні 2015 року.

За період роботи Ресурсного центра (березень 2015 року - квітень 2019 року) до розміщення на електронній сторінці було отримано матеріали від 158 педагогічних працівників, серед них: 79 вихователів дошкільних навчальних закладів; 41 завідувач, методист та вихователь-методист дошкільних навчальних закладів; 6 практичних психологів; 12 керівників музичних; 2 керівники із фрізичного виховання; 3 методисти відділів освіти; 1 вчитель початкових класів; 12 вчителів-логопедів; 1 директор школи-інтернату Донецької, Харківської, Дніпропетровської областей та 1 аспірант.

Після рецензування матеріалів, які надійшли до Ресурсного центру, педагогічні працівники отримали відповідний Сертифрікат про розміщення матеріалів провідного психолого-педагогічного досвіду на електронній сторінці Ресурсного центру. Усього було видано 158 Сертифрікатів.

Зроблено публікацію шести випусків науково-методичного журналу «Альманах психолого-педагогічного досвіду». На сторінках нового видання розміщені матеріали провідного психолого-педагогічного досвіду, який представлено на сторінці Ресурсного центру - валеонасиченого освітнього простору для розвитку студентів, педагогів, психологів, батьків та дітей.

Перший випуск Альманаху було присвячено 50-річчю педагогічного фракультету. Тема другого випуску: «Театр навчає і виховує: театралізована діяльність у дошкільному віці». Третій випуск Альманаху психолого-педагогічного досвіду присвячено проблемі використання сучасних здоров'язбережувальних технологій у практиці роботи закладів дошкільної освіти. У четвертому випуску висвітлено досвід роботи дошкільного навчального закладу № 3 «Ромашка» м. Слов'янська Донецької області. Тема п'ятого випуску: «Актуальні проблеми художньо-естетичного розвитку дітей дошкільного віку». Шостий випуск (спецвипуск) висвітлює досвід роботи з дітьми дошкільного віку, що мають особливі освітні потреби. Триває підготовка сьомого випуску, присвяченого досвіду роботи дошкільного закладу № 55 «Лелека» м. Слов'янська та спецвипуску матеріалів керівників музичних означеного закладу дошкільної освіти, продовжується добір матеріалів наступного випуску про досвід роботи дошкільного закладу № 2 «Оленка» м. Слов'янська Донецької області.

Робота Ресурсного центру відбивається в освітньому процесі педагогічного факультету. Так, 
студенти денної та заочної форм навчання були залучені до підготовки інформаційних матеріалів із дисциплін «Етнопсихологія», «Психологія профорієнтаційної роботи», «Психологія сім'ї», «Психологія педагогічної діяльності», «Психологія виховної роботи» та ін. За результатами науково-методичного пошуку в означених напрямках було підготовлено 3 навчально-методичні посібники, 3 методичні рекомендації 3 дисциплін, 1 довідник з етнопсихології.

Завдання та діяльність Ресурсного центру представлені у наукових публікаціях України та за її межами, а саме: опубліковано 1 статтю у виданні, яке внесено до наукометричної бази Web of Science, 2 статті в журналі, який внесено до наукометричної бази Index Copernicus, 3 статті у фахових виданнях України, 1 закордонна публікація, 1 стаття у нефраховому виданні України.

Робота Ресурсного центру висвітлюється на офріційному сайті ДВНЗ «Донбаський державний педагогічний університет» (http://www.ddpu.edu.ua).

Створено блог Ресурсного центру, який має наступні можливості: здійснення зворотного зв'язку з користувачами; завантаження розміщених матеріалів; пошук інформації за ключовими словами; відбиття кількості переглядів користувачів (11 452 перегляди).

Блог було створено з урахуванням характеристик освітніх блогів (регулярність ведення, колективність, включеність декількох видів мультимедіа, контентність (авторський текст), автономність, мобільність) та типових помилок, які були допущені авторами освітніх блогів (відсутність назви, анонімність, велика кількість сторінок, занадто довгий текст, граматичні та синтаксичні помилки, тривале завантаження сторінки, невдалий дизайн, зайва анімація, відсутність плану, ігнорування соціальних мереж) [3].

Розглянемо структуру та змістовне наповнення освітнього блогу «Ресурсний центр - валеонасичений освітній простір для розвитку студентів, педагогів, психологів, батьків та дітей» (https:// resourcecenterped.blogspot.com).

Сторінки основного меню: «Головна», «Про РЦ», «Новини», «Консультанти РЦ», «Бюлетень РЦ», «Публікації про нас», «Для психолого-педагогічних працівників», «Для фрахівців соціальної сфери», «Альманах психолого-педагогічного досвіду», «Про автора», «Контакти».

На головній сторінці публікуються повідомлення авторів (текст, фрото, відео). Інформація постійно оновлюється та публікується у хронологічному порядку.

На сторінці «Про РЦ» подано інфрормацію про організацію роботи Ресурсного центру, основні напрямки роботи, представлено структуру Ресурсного центру.

Сторінка «Новини» інформує читачів про роботу Ресурсного центру.

На сторінці «Консультанти РЦ» представлено інформацію про викладачів-консультантів педагогічного факультету ДВНЗ «Донбаський державний педагогічний університет».
Сторінка «Бюлетень РЦ». Редакційна колегія Ресурсного центру популяризує результати роботи у Бюлетенях Ресурсного центру. За весь період роботи було зроблено 22 випуски, які презентують доробки педагогічних працівників.

На сторінці «Публікації про нас» представлено матеріали про роботу Ресурсного центру у виданнях України та за її межами.

Сторінки «Для психолого-педагогічних працівників», «Для фрахівців соціальної сфрери» містять практичні матеріали: презентації, тренінги, програми соціально-педагогічної реабілітації та інше, що розроблені викладачами педагогічного фракультету ДВНЗ «Донбаський державний педагогічний університет».

На сторінці «Альманах психолого-педагогічного досвіду» розміщено випуски науково-методичного журналу (шість випусків).

Сторінка «Про автора» містить інформацію про авторів блогу, а саме: освіта, стаж роботи, життєве кредо, сфера наукових інтересів. Інформація розміщена з метою знайомства відвідувачів блогу з авторами.

На сторінці «Контакти» розміщена електронна адреса авторів блогу, за якою відвідувачі надсилають свої запитання.

Перехресна колонка ліворуч (cross-column) містить такі сторінки: «Наші партнери», «На допомогу студентам (підручники on-line)».

На цих сторінках розміщено методичні доробки педагогічних працівників (завідувачів, методистів, вихователів, інструкторів із фрізичного виховання, керівників музичних, практичних психологів, вчителів, логопедів, аспірантів та здобувачів), підручники для самостійного опрацювання студентами.

Також у блозі наявний гаджет «Корисні посилання», у якому розміщено посилання на офріційні сайти, а саме: Міністерство освіти та науки України (https://mon.gov.ua/ua), ДВНЗ «Донбаський державний педагогічний університет» (http://ddpu. edu.ua), Освіта.ua (http://osvita.ua), Методичний портал (http://metodportal.com), Освітній портал (http://www.osvita.org.ua).

3 метою залучення педагогічних працівників дошкільних навчальних закладів та загальноосвітніх шкіл до освітнього блогу «Ресурсний центр - валеонасичений освітній простір для розвитку студентів, педагогів, психологів, батьків та дітей» у соціальній мережі Фейсбук створено групу Ресурсного центру (https://www.facebook. com/groups/resursdopp/), яка налічує понад 1500 учасників, серед яких: завідувачі, вихователі-методисти, вихователі, практичні психологи, керівники музичні дошкільних навчальних закладів та загальноосвітніх шкіл із різних областей України. Група має статус загальнодоступної та кожний охочий може долучитися до неї.

Отже, Ресурсний центр педагогічного фракультету є: сучасною результативною формою інфрормаційного обміну, що передбачає формування віртуальних педагогічних спільнот, використання Інтернетсерверів, розробку комп'ютерних дидактичних матеріалів, формування в психолого-педагогічних 
працівників навичок роботи з електронними ресурсами та масивами інформації; інструмент удосконалення системи підготовки фахівців психолого-педагогічного напряму згідно із сучасними стандартами освіти; можливість налагодження міцних зв'язків викладачів університету та психолого-педагогічних працівників, що є запорукою забезпечення потреб сучасного ринку освітньої діяльності.

Висновки. Отже, проведений аналіз надає можливість стверджувати, що створений на педагогічному факультеті ДВНЗ «Донбаський державний педагогічний університет» Ресурсний центр як валеонасичений простір для розвитку студентів, педагогів, психологів батьків та дітей дошкільного та шкільного віку - це осередок накопичення, систематизації, розповсюдження перспективного психолого-педагогічного досвіду освітян Донеччини.

Перспективи подальшої роботи: проведення вебінарів; консультування педагогічних працівників із підготовки матеріалів психолого-педагогічного досвіду; узагальнення, систематизація та популяризація матеріалів провідного психолого-педагогічного досвіду на сайті та в постійному виданні «Альманах психолого-педагогічного досвіду»; підготовка та видання навчально-методичних посібників.

\section{Список використаної літератури:}

1. Аматьєва О.П., Курінна С.М., Головко М.Б. Ресурсний центр фракультету дошкільної освіти та практичної психології як засіб удосконалення підготовки фахівців. Щомісячний науково-педагогічний журнал Рідна школа. № 3 (березень), 2014. C. 41-46

2. Зотова Е.Б. Управление Ресурсным центром образовательного учреждения: научно-практическая разработка для руководителей образовательных учреждений различного типа и вида, осуществляющих управление инновационной деятельностью в процессе передачи результатов экспериментальной работы в массовую практику. Москва, 2012. 81 с.

3. Набока О.Г., Демченко М.О. Освітній блог як засіб професійної підготовки майбутніх вихователів закладів дошкільної освіти. Інформаційні технології $і$ засоби навчання. Том 69. № 1 (2019). C. 64-77.

4. Тархова Г.А. Сопровождение инклюзивных процессов в образовательных учреждениях. URL: http://innovation.momos.ru/index. php/component/k2/item/24 (дата звернення: 04.05.2019).

5. Троценко Н.Є. Професійне самовдосконалення соціальних працівників у ресурсних центрах : автореф. дис. ... канд. пед. Наук : 13.00.05. Київський ун-т ім. Бориса Грінченка. Київ, 2012. 20 с.

Amatieva O., Demchenko M., Gakalo V. Use of Resource center opportunities for optimization psychological education workers' preparation

The article analyzes the work of the Resource Center - a valence-centered educational environment for students, teachers, psychologists, parents and children of SHEI «Donbas State Pedagogical University». The leading idea and purpose of the Resource Center work are determined. It was emphasized that the activity of the Resource Center of the Faculty of Pedagogy as a valence-centered educational space for the development of students, teachers, psychologists, parents and children is aimed at ensuring the functioning of feedback between its participants.

The results of the Resource Center work are presented, namely: the number of partners involved (teachers of pre-school educational institutions, schools) and Certificates on placement of leading psychological and pedagogical experience on the Resource Center website, issues of the scientific and methodological magazine "Almanac of psychological and pedagogical experience», scientific and methodical manuals, articles in scientific journals of Ukraine and abroad. The Resource Center work in the educational process of the pedagogical faculty of SHEI DSPU is described.

The work of the educational blog «Resource Center - a valence-centered educational environment for the development of students, teachers, psychologists, parents and children» is highlighted, which has the following possibilities: feedback; loading of placed materials; search for information by keywords; display the number of users' views. The structure and content of the educational blog are characterized. The main menu pages are: "Home", "About RS", "News", "Consultants of the RC", "Bulletin of the RC", "Publications about us", "For psychologists and pedagogical workers", "For specialists of social sphere", "Almanac of psychological and pedagogical experience", "About the author", "Contacts"; cross-column pages: "Our partners", "To help students (on-line tutorials)".

It is determined that the information kernel of the Resource Center is a unique intellectual base of high school teachers providing access to informational, scientific and methodical, educational information resources with the ability to transform themselves and society.

Key words: Resource center, students, educational blog, pedagogical staff, pre-school institution. 